\title{
Impact of Ferritin Load on Gonadal Reserve among Regular Transfused $\beta$-Thalassemia
}

\author{
Hasnaa A. Abo-Elwafa1, Safa A. Hamid², Mena M. Heshmat², Zahra S. Ahmed ${ }^{2}$ \\ ${ }^{1}$ Clinical Pathology Department, Faculty of Medicine, Sohag University, Sohag, Egypt \\ ${ }^{2}$ Pediatric Department, Faculty of Medicine, Sohag University, Sohag, Egypt \\ Email: hasnaa_aboalwafa@med.sohag.edu.eg
}

How to cite this paper: Abo-Elwafa, H.A., Hamid, S.A., Heshmat, M.M. and Ahmed, Z.S. (2017) Impact of Ferritin Load on Gonadal Reserve among Regular Transfused $\beta$-Thalassemia. Open Journal of Blood Diseases, 7, 65-78.

https://doi.org/10.4236/ojbd.2017.72007

Received: April 28, 2017

Accepted: June 23, 2017

Published: June 26, 2017

Copyright (๑) 2017 by authors and Scientific Research Publishing Inc. This work is licensed under the Creative Commons Attribution-NonCommercial International License (CC BY-NC 4.0). http://creativecommons.org/licenses/by-nc/4.0/

\begin{abstract}
Background: Iron overload in association with persistent anemia is responsible for endocrine dysfunction in $\beta$-thalassemia patients, blood transfusion combined with iron-chelation can modify life quality in these children, but they tend to suffer from delayed maturity and endocrine dysfunction. Aim: This study aims to correlate degree of hypogonadism to ferritin load in regular transfused $\beta$-thalassemia patients. Methods: It was carried out on $30 \beta$-thalassemia major (TM) patients aged 12 to 18 years, puberty was assessed clinically, blood picture on Cell-Dyne 2700, ferritin level and pattern of FSH, LH, testosterone and estradiol before and after gonadotropin $(\mathrm{GnRH})$ analogue stimulation test, they were determined on ARCHITECT ABBOTT system. Results: Twenty patients had not yet achieved puberty, FSH level was $1.45 \pm 1.88$ $\mathrm{mIU} / \mathrm{ml}$ before $(\mathrm{GnRH})$ analogue and $3.78 \pm 4.19 \mathrm{mIU} / \mathrm{ml}$ after 4 hours of injection. $\mathrm{LH}$ level was $1.91 \pm 4.79 \mathrm{mIU} / \mathrm{ml}$ before $(\mathrm{GnRH})$ test, while after 4 hours it was $6.52 \pm 7.50 \mathrm{mIU} / \mathrm{ml}, 88.24 \%$ of males had low serum testosterone level, $84.6 \%$ of girls had low serum estradiol level, FSH, LH, estradiol, testosterone before and after GNRH analogue were statistically insignificant, mean ferritin level was $3344.32 \pm 1142.142 \mathrm{ng} / \mathrm{ml}$, with insignificant correlation to hormonal pattern before and after GnRH therapy. Conclusion: Iron overload and hypogonadism are the presenting data in this study, insignificant correlation between ferritin level and hormonal reserve pattern, there may be another etiology in pathophysiology of low gonadal reserve such as severe anemia, chronic disease and may be genetic predisposition underlying susceptibility to iron toxicity, which need further investigations.
\end{abstract}

\section{Keywords}

Ferritin, $\beta$-Thalassemia, Hypogonadism

\section{Introduction}

Thalassemia is a hereditary chronic anemia highly prevalent in the Mediterra- 
nean countries [1]. $B$-thalassemia is the most frequent type of thalassemia. Anemia and iron overload are responsible for endocrine dysfunction in $\beta$-thalassemia [2]. Though meticulous management has prolonged the life expectancy of these patients, they tend to suffer from growth retardation and endocrine dysfunction that are multifactorial in etiology and may be can't prevent by treatment [3]. If regular transfusion program is initiated to maintain the hemoglobin (Hb) level $9-10 \mathrm{~g} / \mathrm{dl}$, normal growth occurs till the age of $10-12$ years old. It is also important to decrease iron overload by adequate chelation to prevent organ damage from free radical [3]. Blood transfusion and iron-chelation therapy together have improved the quality of life [4]. Iron chelation is the only method for iron overload control. Despite chelation therapy, anterior pituitary endocrine axis is sensitive to free radicles and iron deposition [5]. Iron deposition on the pituitary gonadotrophic cells result in disruption of gonadotropin production with hypo gonadotrophic hypogonadism and short stature [6]. Normal rate of prepubertal maturation is observed in some patients with regular transfusion, but delayed sexual maturity was noticed in a well transfused child [7]. Impaired puberty in these patients includes delayed puberty, arrested puberty and hypogonadism [5]. Lack of pubertal changes was the most common endocrine complication, in $\beta \mathrm{TM}$ patients who had hypogonadism [8]. De Sanctis and coworkers found that the puberty was delayed in $18.4 \%$ of boys and $17.7 \%$ of girls [9]. Flynn with his coworkers reported that there was no direct relationship between the amount of iron accumulated and organ dysfunction [10]. Borgna evaluated TM patients and reported about 50\% had hypogonadism [11]. But another study by Low in 2008, had reported that spontaneous puberty occurred in $32 \%$ of the patients only [12].

\section{Patients and Methods}

It is a prospective study; done on thirty $\beta$-TM patients, seventeen boys and thirteen girls, their age ranged from 12 to 18 years old. They were selected from the Hematology Outpatient Clinic in Sohag University Hospital. Cases were recruited during the study period from July 2013 to June 2014. Because we investigate the gonadal reserve reflected by the response to $\mathrm{GnRH}$ analogue stimulation test to hypothalamic pituitary gonadal axis; as a therapeutic test being already done in these patients group, but in normal healthy boys and girls we can't apply this test to avoid hormonal disturbance during this critical period. Instead control group we used the documented reference values to determine hypogonadism and consider $\beta \mathrm{TM}$ patients who reach the normal puberty for comparison.

\subsection{Inclusion Criteria}

$\beta$-TM patients with iron overload on chelating therapy, their serum ferritin more than $1000 \mathrm{ng} / \mathrm{ml}$; aged 12 - 18 years old on regular transfusion program 1: 2 packed RBCs units at frequency/2 weeks to 3 months according to Hb level and body weight, to maintain hemoglobin level more than $9 \mathrm{~g} / \mathrm{dl}$. 


\subsection{Exclusion Criteria}

Pediatric patients less than 12 years or received hormonal replacement therapy as estrogen, progesterone, testosterone or GnRH analogue or had another disease that delayed puberty. Other causes of iron over load rather than $\beta$ TM like hereditary hemochromatosis

\subsection{Ethical Consideration}

Approval of Sohag Faculty of Medicine Research Ethical Committee and consent from the parents will be obtained.

\subsection{Methods}

All cases included in this work will be subjected to complete history, clinical evaluation for weight, age, and sexual developmental, degree of pallor, Jaundice and general condition. Pubertal stages were determined by Marshal and Tanner scale of physical development in children, adolescents and adults [13].

\subsection{Laboratory Investigation}

blood samples were taken from patients at morning at least two weeks after the blood transfusion; total of $3 \mathrm{ml}$ blood was withdrawn from each patient delivered into K-EDTA tube for complete blood picture using electronic counter Cell Dyne 2700 (USA), and reticulocyte count was assayed, then centrifuged, the plasma was delivered to ARCHITECT i Optical System, Abbott Ireland Diagnostics Division, Chemiluminescent Microparticle Immunoassay (CMIA) for the quantitative determination of ferritin, FSH, LH and testosterone. The patients were subjected to GnRH stimulation test (subcutaneous injection of $0.1 \mathrm{mg}$ decapeptyl; GnRH analogue to detect response of pituitary to $\mathrm{GnRH}$ ), four hours later, the second sample was taken and subjected to post GnRH stimulation test hormonal assay, and then the hormonal levels were correlated with the pubertal scale of the patients and ferritin level.

\subsection{ARCHITECT Ferritin Assay}

Ref. No. B7K590/49-1515/R4 [14].

Assay procedure: Is a two-step immunoassay to determine ferritin in serum or plasma using a chemiluminescent microparticle immunoassay (CMIA) technology with flexible assay protocol, referred to as chemiflex. In the first step, sample and anti-ferritin coated paramagnetic microparticles are combined. Ferritin present in the sample binds to the ant ferritin coated micro particles. After washing, anti-ferritin acridinium labeled conjugate is added in the second step, pre-trigger and trigger solutions are then added to the reaction mixture; the resulting chemiluminescent reaction is measured as relative light units (RLUs). A direct relationship exists between the amount of ferritin in the sample and the RLUs detected by using the Architect $i$ optical system. Before loading the ARCHITECT ferritin reagent kit on the system for the first time, the micropar- 
ticles bottle was mixed to resuspend microparticles that have settled by inverting the microparticles bottle 30 times. Then we inspect the microparticles if microparticles are still adhered to the bottle, repeat mixing until the microparticles have been completely resuspended. Once the microparticles have been suspending, the cap was removed and discards, and the reagents were loaded on the ARCHITECT I System. ARCHITECT ferritin calibrators, ARCHITECT ferritin controls should be mixed by gentle inversion prior to use, hold the bottles vertically and 4 drops were dispensed of each calibrator or 3 drops of each control into each respective sample cup. Then the samples were loaded. When we press RUN the ARCHITECT $i$ System performs the following function: moves the sample to the aspiration point, loads a reaction vessel (RV) into the process rout, aspirates and transfers sample into the RV, advances the RV one position and transfers microparticles into the $\mathrm{RV}$, mixes, incubates and washes the reaction mixture, adds conjugate to the RV, mixes, incubates and washes the reaction mixture, adds pre-trigger and trigger solutions, measures chemiluminescent emission to determine the quantity of ferritin in the sample, aspirates contents of $\mathrm{RV}$ to liquid waste and unloads RV to solid waste. Calibration: perform an ARCHITECT ferritin calibration, test ARCHITECT ferritin calibrators 1 and 2 in duplicate. A single sample of all levels of ARCHITECT ferritin controls must be tested to evaluate the assay calibration. Calibrators should be priority loaded. The assay protocol extends the assay range to $0-2000 \mathrm{ng} / \mathrm{ml}$. Once an ARCHITECT Ferritin calibration is accepted and stored, all subsequent samples may be tested without further calibration. Normal ferritin range in males is 21.81 - $274.66 \mathrm{ng} / \mathrm{ml}$ and the mean is $75.62 \mathrm{ng} / \mathrm{ml}$, for females the range is $4.63-204.0$ $\mathrm{ng} / \mathrm{ml}$ and the mean is $39.42 \mathrm{ng} / \mathrm{ml}$.

The following assays were processed by ARCHITECT in the same way as ferritin.

\subsection{ARCHITECT FSH Assay}

Ref. No. B7K750 G4-5970/R09 [15]. Normal FSH range is $0.95-11.95 \mathrm{mIU} / \mathrm{ml}$ at puberty. Values to $\mathrm{GnRH}$ analogue stimulation test: no response: $<0.95 \mathrm{mIU} /$ $\mathrm{ml}$, mild increase: 0.95 - $5 \mathrm{mIU} / \mathrm{ml}$, moderate increase: 5 - 11, high increase: $>11$ $\mathrm{mIU} / \mathrm{ml}$.

\subsection{ARCHITECT LH Assay}

Ref. No. B2P400/G3-0641/R04 [16]. LH range at puberty is $0.57-12.07$ for male, $0.3-31.0 \mathrm{mIU} / \mathrm{ml}$ for females. Values to $\mathrm{GnRH}$ analogue test: no response: $<0.3$ $\mathrm{mIU} / \mathrm{ml}$, mild increase: $0.3-10 \mathrm{mIU} / \mathrm{ml}$, moderate increase: $10-20 \mathrm{mIU} / \mathrm{ml}$, high increase : $>20 \mathrm{mIU} / \mathrm{ml}$.

\subsection{ARCHITECT Testosterone Assay}

Ref. No. B2 P130/ABB L311/R07AxS [17]. Normal testosterone range at puberty for male: $2.41-8.27 \mathrm{ng} / \mathrm{ml}$. 


\subsection{ARCHITECT Estradiol}

Ref.No.B2K 3C85-20/AxS [18]. Normal estradiol range at puberty for female: 15 $-350 \mathrm{pg} / \mathrm{dl}$.

\section{Statistical Analysis}

$\mathrm{Z}$ test; test of proportion was used to compare between 2 percentages, Chisquare test $\left(\mathrm{x}^{2}\right)$ was used to compare between more than 2 percentages, Student " $t$ " test to compare 2 mean and S.D of 2 groups, Paired " $t$ " test was used to compare between 2 mean and S.D in the same group before and after treatment, ANOVA test was used to compare between different groups.

\section{Results}

The current study was included $30 \beta$-TM patients; seventeen boys (56.67\%) and thirteen girls (43.33\%). The mean age of the patients was $13.91 \pm 2.14$ years; the mean of weight was $31.4 \pm 7.98 \mathrm{~kg}$; the mean of height was $134.23 \pm 15.60 \mathrm{~cm}$. As regard head circumference was $53.07 \pm 2.80 \mathrm{~cm}$. The mean frequency of blood transfusion was $1.06 \pm 0.29 /$ month. Splenectomy was done in 23 patients (76.67\%). All the cases (30 patients) had taken routine vaccination. HCV infection was detected in 7 patients (23.33\%), and no one had HBsAg. The demographic, anthropometric and clinical data were represented in Table 1. As re

Table 1. Clinical and laboratory data of the patients.

\begin{tabular}{cc}
\hline Item & Statistical values \\
\hline Age in years (mean \pm S.D) & $13.91 \pm 2.14$ \\
male/female & $17 / 13$ \\
Weight /kg (mean \pm S.D) & $31.4 \pm 7.98$ \\
Height in cm (mean \pm S.D) & $134.23 \pm 15.6$ \\
Head circumference (cm) (mean \pm S.D) & $53.07 \pm 2.80$ \\
Frequency of blood transfusion unit/month (mean \pm S.D) & $1.06 \pm 0.29$ \\
Splenectomy (case) & 23 \\
Vaccination (case) & 30 \\
HCV positive (case) & 7 \\
HBsAg positive (case) & 0 \\
RBCs $\times 10^{9} /$ (mean \pm S.D) & $2.62 \pm 0.68$ \\
Hb g/dl (mean \pm S.D) & $6.79 \pm 1.77$ \\
Hct \% (mean \pm S.D) & $22.06 \pm 4.89$ \\
Ferritin ng/ml (mean \pm S.D) & $3344.32 \pm 1142.142$ \\
FSH mIU/ml (mean \pm S.D) & $1.45 \pm 1.88$ \\
LH mIU/ml (mean \pm S.D) & $1.91 \pm 4.79$ \\
Estradiol pg/dl (mean \pm S.D) & $11.02 \pm 18.80$ \\
Testosterone ng/ml (mean \pm S.D) & $17.0 \pm 0.68$ \\
\hline
\end{tabular}

FSH: Follicle Stimulating Hormone, LH: Luteinizing Hormone, HCV: Hepatitis C virus, HBsAg: Hepatitis B virus surface antigen, RBCs: Red Blood Cells, Hb: Hemoglobin, Hct: Hematocrit. 
gard Tanner scale, there was twenty cases $(66.67 \%)$ had not attained puberty in stage (1). Seven cases (23.33\%) were belonging to stage (2). Stage (3) has 2 cases $(6.67 \%)$. There is only one case in stage (4). The hormonal pattern in these patients before and after GnRH analogue stimulation test showed FSH level was $1.45 \pm 1.88 \mathrm{mIU} / \mathrm{ml}$ before and after 4 hours it was $3.78 \pm 4.19 \mathrm{mIU} / \mathrm{ml}$. FSH level was highly significant low in $60 \%$ of cases with p-value $<0.0001$. Also LH level was $1.91 \pm 4.79 \mathrm{mIU} / \mathrm{ml}$ before $\mathrm{GnRH}$, while after 4 hours of $\mathrm{GnRH}$ therapy it was $6.52 \pm 7.50 \mathrm{mIU} / \mathrm{ml}$, LH level was highly significant low in half of the patients; with p-value $<0.0001$.The testosterone level was $17 \pm 0.68 \mathrm{ng} / \mathrm{ml}$. Fifteen boys (88.24\%), had low serum testosterone level, and only two had normal level. While the mean estradiol level in the girls was $11.02 \pm 18.80 \mathrm{pg} / \mathrm{dl}$, about eleven girls $(84.62 \%)$ had low level of serum estradiol and only two cases (15.38\%) had normal estradiol level as in Table 2.

When we correlate ferritin levels to hormonal pattern, we found that; FSH level before GnRH analogue was low in eighteen patients with the mean ferritin level $3578.52 \mathrm{ng} / \mathrm{ml}$, and twelve patients had normal FSH with the mean ferritin

Table 2. Relation between Tanner scale and hormonal pattern.

\begin{tabular}{|c|c|c|c|c|c|}
\hline $\begin{array}{l}\text { Tanner Scale } \\
\text { Number (N) }\end{array}$ & $\begin{array}{c}1 \\
N=20\end{array}$ & $\begin{array}{c}2 \\
N=7\end{array}$ & $\begin{array}{c}3 \\
N=2\end{array}$ & $\begin{array}{c}4 \\
N=1\end{array}$ & $\mathbf{P}$-values \\
\hline & nRH test & & & & \\
\hline \multicolumn{6}{|l|}{$\mathrm{FSH} \mathrm{mIU} / \mathrm{ml}$} \\
\hline Low & 15 & 2 & 0 & 1 & $0.04 \mathrm{~S}$ \\
\hline Normal & 5 & 5 & 2 & 0 & \\
\hline \multicolumn{6}{|l|}{$\mathrm{LH} \mathrm{mIU} / \mathrm{ml}$} \\
\hline Low & 13 & 1 & 0 & 1 & $0.13 \mathrm{NS}$ \\
\hline Normal & 6 & 6 & 2 & 0 & \\
\hline High & 1 & 0 & 0 & 0 & \\
\hline \multicolumn{6}{|l|}{ Estradiol pg/dl } \\
\hline Low & 6 & 3 & 2 & 0 & $0.48 \mathrm{NS}$ \\
\hline Normal & 2 & 0 & 0 & 0 & \\
\hline \multicolumn{6}{|c|}{ Testosterone ng/ml } \\
\hline Low & 11 & 3 & 0 & 1 & $0.62 \mathrm{NS}$ \\
\hline Normal & 1 & 1 & 0 & 0 & \\
\hline \multicolumn{6}{|c|}{ Post GnRH test } \\
\hline \multicolumn{6}{|l|}{$\mathrm{FSH} \mathrm{mIU} / \mathrm{ml}$} \\
\hline No & 8 & 1 & 0 & 0 & \\
\hline Mild & 9 & 4 & 0 & 1 & $0.13 \mathrm{NS}$ \\
\hline Moderate & 2 & 1 & 2 & 0 & \\
\hline Good & 1 & 1 & 0 & 0 & \\
\hline \multicolumn{6}{|l|}{$\mathrm{LH} \mathrm{mIU} / \mathrm{ml}$} \\
\hline No & 5 & 1 & 0 & 0 & \\
\hline Mild & 11 & 3 & 0 & 1 & $0.42 \mathrm{NS}$ \\
\hline Moderate & 3 & 3 & 2 & 0 & \\
\hline Good & 1 & 0 & 0 & 0 & \\
\hline
\end{tabular}


level $2954.58 \mathrm{ng} / \mathrm{ml}$. About the LH pattern we noticed that, before GnRH analogue, fifteen patients had low LH level with the mean ferritin level $3481.20 \mathrm{ng} / \mathrm{ml}$, and fourteen cases had normal LH level, their ferritin level was $3027.00 \mathrm{ng} / \mathrm{ml}$, only one case with high LH level; the ferritin was $5272.00 \mathrm{ng} / \mathrm{ml}$. After GnRH stimulation test we found that, FSH had good response in 2 cases $(6.67 \%)$, their mean ferritin was $1118.95 \mathrm{ng} / \mathrm{ml}$, mild response in 14 cases $(46.67 \%)$ and moderate response in 5 cases (16.67\%), their mean ferritin level was 314,289 and 3117.24 respectively. No response was found in 9 patients (30\%) with the mean ferritin level was $4227.4 \mathrm{ng} / \mathrm{ml}$. While LH after GnRH therapy revealed the following; only one case (3.33\%) had good response LH more than $20 \mathrm{mIU} / \mathrm{ml}$ with the mean ferritin level was $5272.0 \mathrm{ng} / \mathrm{ml}$, mild response in 15 cases $(50 \%)$; their ferritin level was $2712.9 \mathrm{ng} / \mathrm{ml}$, moderate response in 8 patients $(26.67 \%)$, with the mean ferritin was $3106.6 \mathrm{ng} / \mathrm{ml}$, and no response in 6 patients $(20 \%)$, their mean ferritin was $4841.6 \mathrm{ng} / \mathrm{ml}$. These data were presented in Table 3 and Figure 1, Figure 2. As regard the correlation between ferritin level and estradiol levels; we found $84.62 \%$ of females (eleven girls) had low estradiol with the mean ferritin level was $2731.38 \mathrm{ng} / \mathrm{ml}$, and only two girls had high estradiol their ferritin was $2316.55 \mathrm{ng} / \mathrm{ml}$. We notice that, in fifteen boys with low testosterone level; the ferritin level was $3945.20 \mathrm{ng} / \mathrm{ml}$ and two boys with normal testosterone level, ferritin was $3006.00 \mathrm{ng} / \mathrm{ml}$. These data are illustrated in Table 3 and Figure 3.

Table 3. Ferritin load in relation to hormonal pattern.

\begin{tabular}{|c|c|c|c|c|c|}
\hline Items & Hormonal Pattern & Patient & r and $(\%)$ & Mean ferritin ng/ml & $P$ value \\
\hline \multicolumn{6}{|c|}{ Pre GnRH test } \\
\hline \multirow{3}{*}{$\mathrm{FSH} \mathrm{mIU} / \mathrm{ml}$} & Low & 18 & 60 & 3578.52 & 0.46 \\
\hline & Normal & 12 & 40 & 2954.58 & NS \\
\hline & Low & 15 & 50 & 3481.20 & \\
\hline \multirow[t]{2}{*}{$\mathrm{LH} \mathrm{mIU} / \mathrm{ml}$} & Normal & 14 & 46.67 & 3027.00 & 0.59 \\
\hline & High & 1 & 3.33 & 5272.00 & NS \\
\hline Estradiol & Low & 11 & 84.62 & 2731.38 & 0.71 \\
\hline $\mathrm{pg} / \mathrm{dl}$ & Normal & 2 & 15.38 & 2316.55 & NS \\
\hline \multirow{2}{*}{$\begin{array}{c}\text { Testosterone } \\
\mathrm{ng} / \mathrm{ml}\end{array}$} & Low & 15 & 88.24 & 3945.20 & 0.64 \\
\hline & Normal & 2 & 11.78 & 3006.00 & NS \\
\hline \multicolumn{6}{|c|}{ Post GnRH test } \\
\hline \multirow{4}{*}{$\mathrm{FSH} \mathrm{mIU} / \mathrm{ml}$} & No & 9 & 30 & 4227.40 & \\
\hline & Mild & 14 & 46.67 & 3142.69 & 0.31 \\
\hline & Moderate & 5 & 16.67 & 3117.24 & NS \\
\hline & Good & 2 & 6.67 & 1118.95 & \\
\hline \multirow{4}{*}{$\mathrm{LH} \mathrm{mIU} / \mathrm{ml}$} & No & 6 & 20 & 4841.60 & \\
\hline & Mild & 15 & 50 & 2712.92 & 0.18 \\
\hline & Moderate & 8 & 26.67 & 3106.61 & NS \\
\hline & Good & 1 & 3.33 & 5272.00 & \\
\hline
\end{tabular}

FSH: Follicle Stimulating Hormone: no response: $<0.95 \mathrm{mIU} / \mathrm{ml}$, mild increase: $0.95-5 \mathrm{mIU} / \mathrm{ml}$, moderate increase: 5 - 11 high increase: $>11 \mathrm{mIU} / \mathrm{ml}$, LH: Luteinizing Hormone: no response: $<0.3 \mathrm{mIU} / \mathrm{ml}$, mild increase: 0.3 - $10 \mathrm{mIU} / \mathrm{ml}$, moderate increase: $10-20 \mathrm{mIU} / \mathrm{ml}$, high increase: $>20 \mathrm{mIU} / \mathrm{ml}$, Estradiol: 15 - 350 pg/dl, Testosterone: 2.4 - $8.2 \mathrm{ng} / \mathrm{ml}$, GnRH: Gonadotropin Releasing Hormone. 


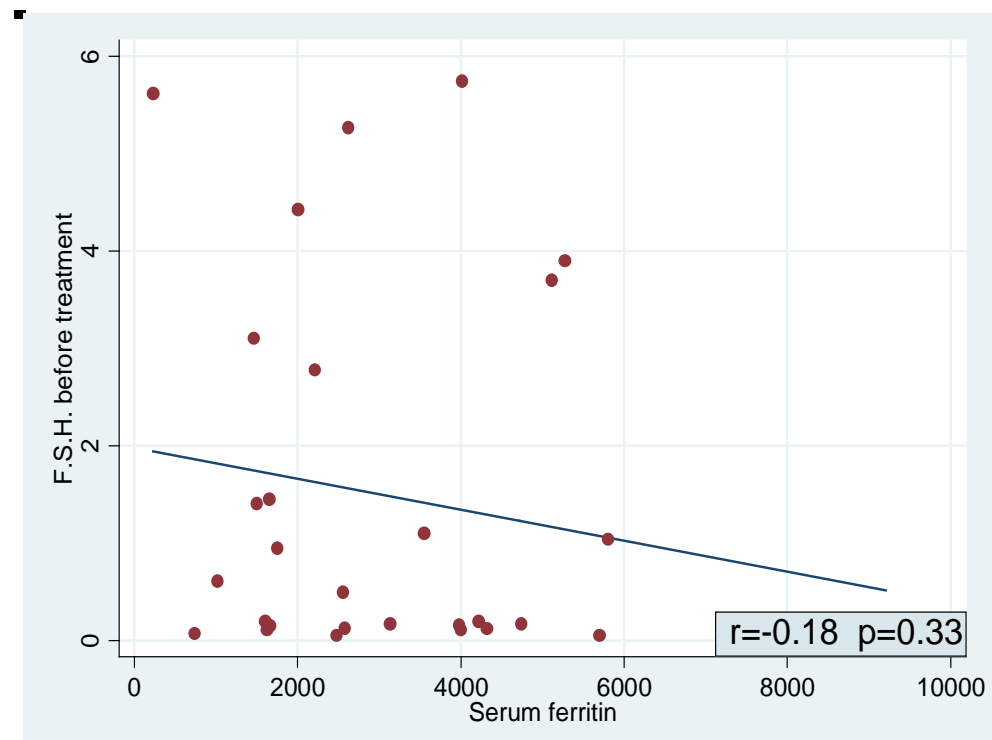

(a)

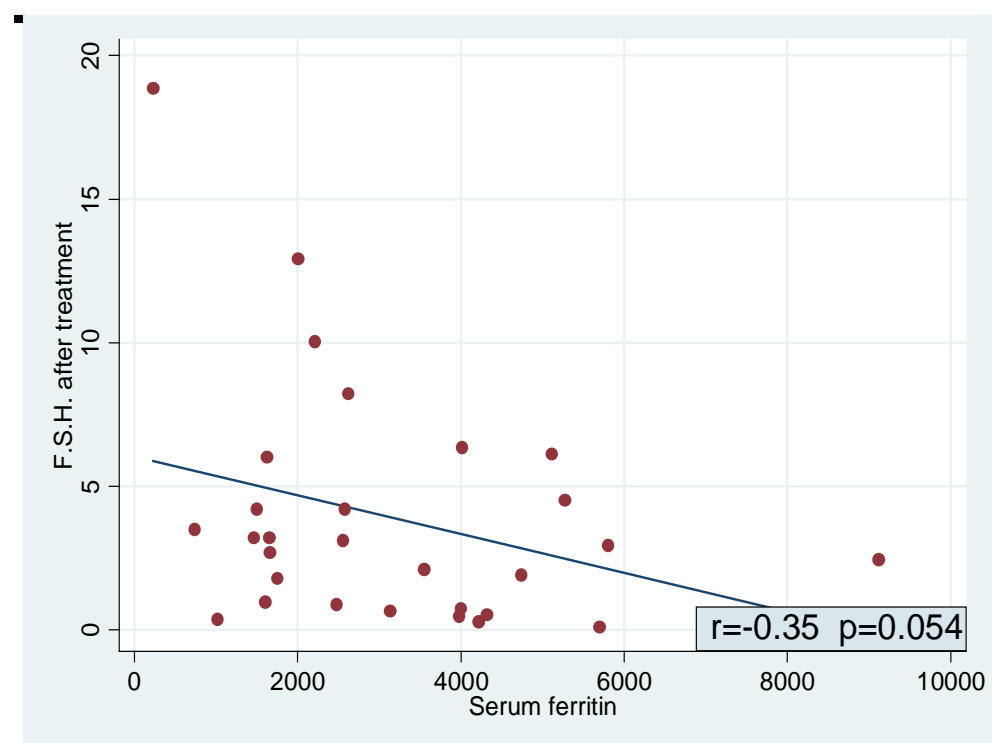

(b)

Figure 1. Correlation of ferritin level to FSH before GnRH analogue therapy (a) $p=0.33$, $\mathrm{r}=0.18$ and after GnRH therapy (b) $\mathrm{p}=0.054, \mathrm{r}=0.35$. FSH: Follicle Stimulating Hormone $\mathrm{mIU} / \mathrm{ml}, \mathrm{GnRH}$ : Gonadotropin Releasing Hormone.

The real distribution pattern of ferritin level for each individual patient was illustrated in Figure 4.

\section{Discussion}

$B$-TM patients characterized by repeated blood transfusions with iron deposition in different organs like liver, heart, and the endocrine glands, so tissue damage and organ failure occurred [19]. Iron overload in these patients causes significant morbidity and mortality [20]. Previous studies have established the role of the iron chelator deferoxamine in preventing complications related to iron 


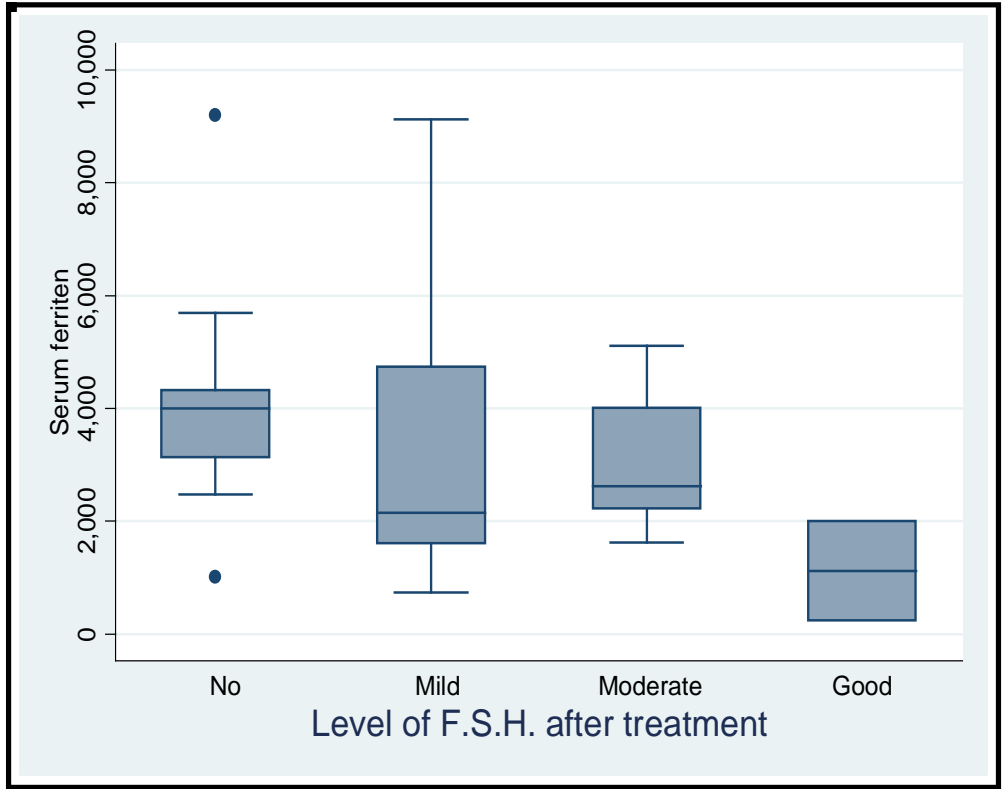

(a)

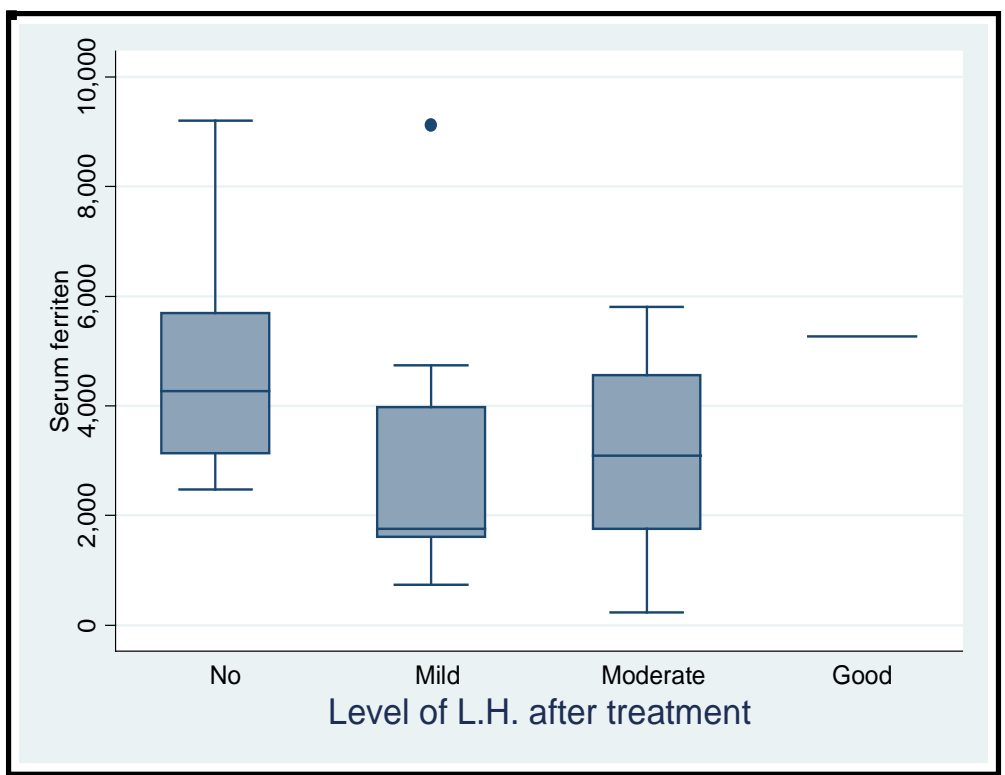

(b)

Figure 2. Correlation of ferritin level to FSH (A) and LH (B) after GnRH analogue therapy. FSH: no response: $<0.95 \mathrm{mIU} / \mathrm{ml}$, mild increase: $0.95-5 \mathrm{mIU} / \mathrm{ml}$, moderate increase: 5 - 11 high increase: $>11 \mathrm{mIU} / \mathrm{ml}$, LH: no response: $<0.3 \mathrm{mIU} / \mathrm{ml}$, mild increase: $0.3-10$ $\mathrm{mIU} / \mathrm{ml}$, moderate increase: 10 - $20 \mathrm{mIU} / \mathrm{ml}$, high increase: $>20 \mathrm{mIU} / \mathrm{ml}$.

overload and improving overall survival. Despite the use of iron chelation therapy, the pituitary gland, peripheral endocrine tissues and gonadal axis are susceptible to iron toxicity [5]. Tissues damage is due to free radical and lipid peroxidation causing mitochondrial, lysosomal and sarcolemmal membrane destruction [21]. Accumulation of iron in various organs may result in the known complications, including diabetes, hypogonadism, hypothyroidism and low bone mass [22]. Lack of sexual maturity was the common findings in a study was done 


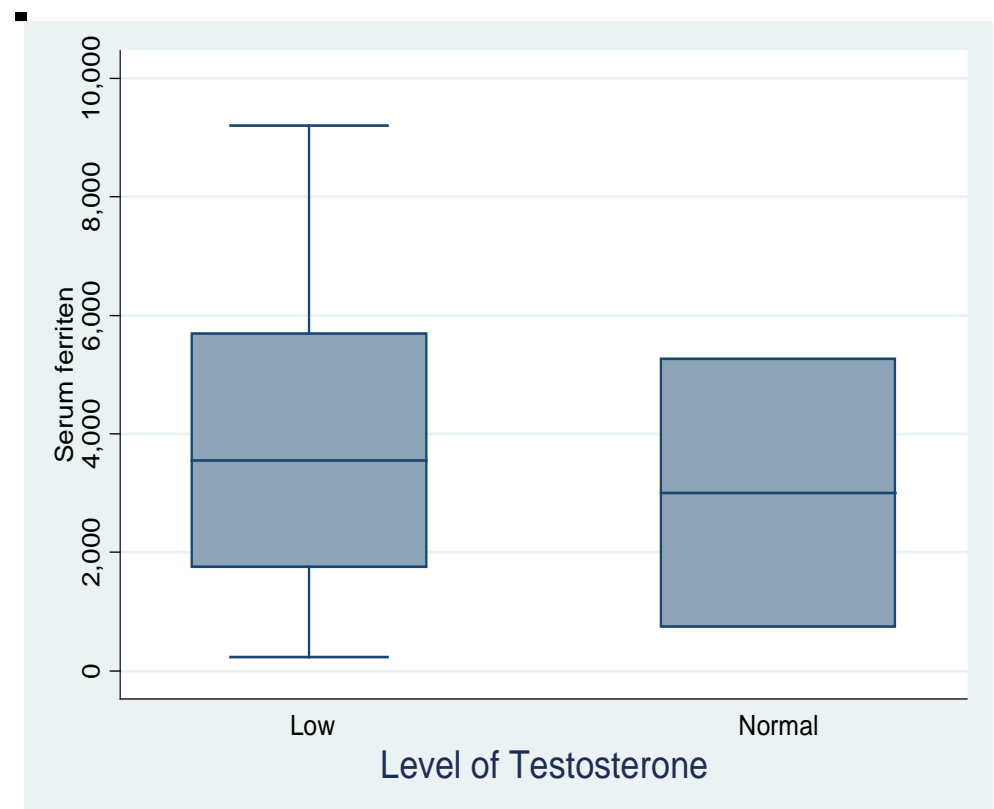

(a)

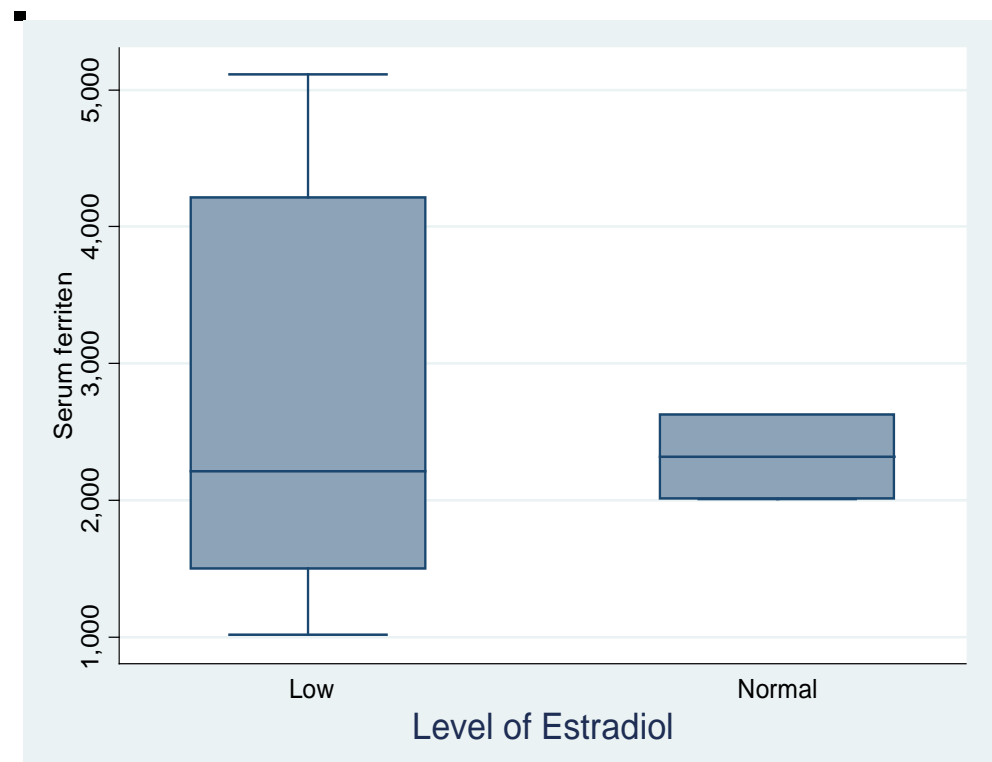

(b)

Figure 3. Ferritin level in relation to testosterone (a) and estradiol (b) level.

on eleven girls only 3 of them at eighteen years old had regular menses, six of twenty boys at nineteen years old; had the criteria for puberty and overall, $22 \mathrm{pa}$ tients had hypogonadism [8]. Also, De Sanctis and coworkers, (2006) evaluated patients with $\beta$-TM of whom thirty-six per cent of patients showed lack of sexual maturity [23]. In the current study, there is very low gonadal reserve, reflected by FSH levels and LH levels which were low before and after giving GnRH analogue, also most of the boys had low testosterone level and the girls had low level of estradiol. The noticed low endocrine reserve in our data was in agreement with Ghosh et al., (2008) and Rashid et al., (2011) [3] [24]. In contrast to our re- 


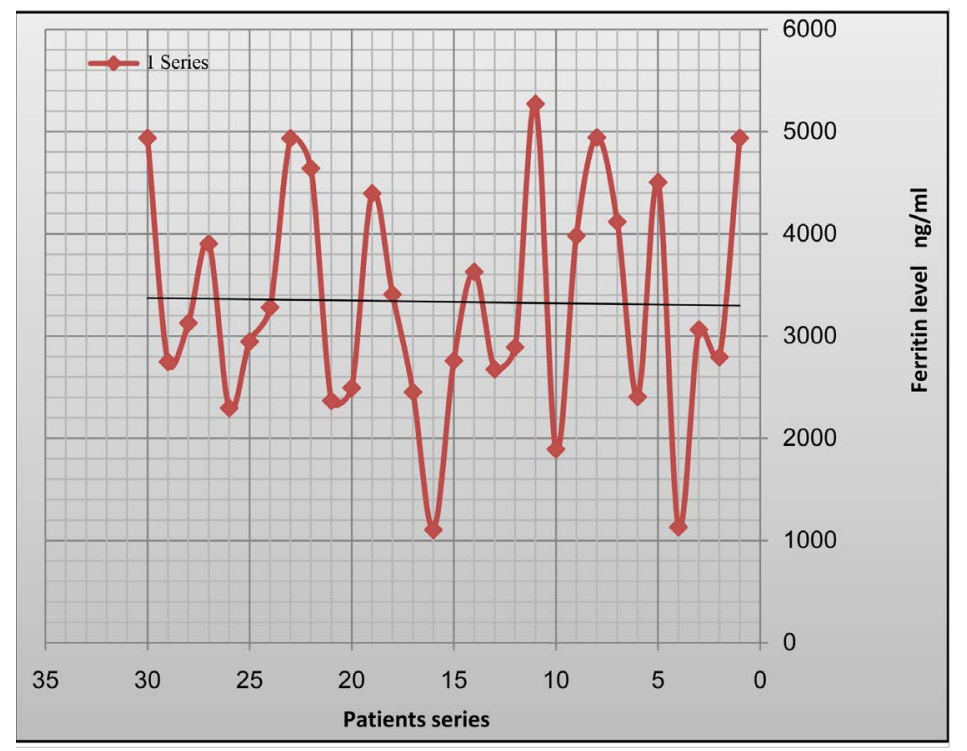

Figure 4. Real distribution of ferritin in each patient.

sult, others found that; within the low gonadotropin reserves, most of the patients with delayed puberty showed normal response to exogenous GnRH [12]. Our study showed that, $100 \%$ of cases had high ferritin load. The mean levels of ferritin depend on several factors, including age at presentation, frequency of transfusion, duration and efficacy of chelation therapy [25] [26] [27]. Correlation between serum ferritin load and hormonal reserve of FSH, LH, estradiol and testosterone by $\mathrm{GnRH}$ analogue test, is insignificant. This was in accordance with Rashid et al. (2011) who postulated that pituitary gland is highly sensitive to iron toxicity and even small amounts of iron accumulated in the early years of life can cause irreversible damage [3]. Harish et al., (2011); also was reported that minimal siderosis, with reduced number of primordial follicles, and thickened ovarian capsules was noticed in these patients [28]. The reason for why the correlation between serum ferritin and sex hormones pattern or gonadal reserve was non-significant in this study and other studies, we can postulate that there are other etiological factors responsible for hypogonadism in these patients, the most important one is chronic persistent anemia; this can confirmed by the fact that; the single patient who had high LH post stimulation test, his Hb level was highest one. Also hepatic affection may be responsible factor as seven patients in this study had HCV infection. Synchronous association of other endocrine dysfunction as hypothyroidism, also we can't exclude genetic predisposition that can increase tolerance to iron overload or susceptibility to iron toxicity as the patient who had increased response to $\mathrm{GnRH}$ test, his ferritin level is above 5000 $\mathrm{ng} / \mathrm{ml}$ despite other patient with serum ferritin varies between $2000-4000 \mathrm{ng} / \mathrm{ml}$ has no response.

\section{Conclusion}

From our data, we can conclude that there is prominent decrease in gonadal re- 
serve with striking iron overload in these patients, but a non-significant correlation between them was detected. These findings can open the way for thinking about other etiological aspects and pathophysiological mechanisms that lead to delayed sexual maturity, such as genetic predisposition increase susceptibility to iron toxicity or increase tolerance to iron overload; other factors, the most important $\mathrm{Hb}$ level and synchronous endocrine affection, so further investigations are necessary for proper management.

\section{Recommendation}

$\beta$-TM patients during adolescence must be subjected to throughout investigations and follow up program to keep the gonadal reserve at a range that maintain normal life.

\section{References}

[1] Pennell, D.J., Porter, J.B., Piga, A., Lai, Y.R., El-Beshlawy, A., Elalfy, M., Yesilipek, A., Kilinc, Y., Habr, D., Musallam, K.M., Shen, J. and Aydinok, Y. (2015) Sustained Improvements in Myocardial T2*over 2 Years in Severely Iron-Overloaded Patients with $\beta$-Thalassemia Major Treated with Deferasirox. American Journal of Hematology, 90, 91-96. https://doi.org/10.1002/ajh.23876

[2] Joshi, R. and Phatarpekar, A. (2013) Endocrine Abnormalities in Children with Beta Thalassemia Major. Sri Lanka Journal of Child Health, 42, 81-86. https://doi.org/10.4038/sljch.v42i2.5628

[3] Merchant, R.H., Shirodkar, A. and Ahmed, J. (2011) Evaluation of Growth, Puberty and Endocrine Dysfunctions in Relation to Iron Overload in Multi Transfused Indian Thalassemia Patients. Indian Journal of Pediatrics, 78, 679-683.

[4] Raiola, G., Galati, M.C., De Sanctis, V., Caruso Nicoletti, M., Pintor, C. and De Simone, M. (2003) Growth and Puberty in Thalassemia Major. Journal of Pediatric Endocrinology and Metabolism, 16, 259-266.

[5] Saffar, F., Mahyar, A. and Jalilolgadr, S. (2012) Endocrine and Metabolic Disorders in Beta-Thalassemia Major Patients. Caspian Journal of Internal Medicine, 3, 466472.

[6] Kyriakou, A. and Skordis, N. (2009) Thalassemia and Aberrations of Growth and Puberty. Mediterranean Journal of Hematology and Infectious Diseases, 1, e2009003.

[7] Brittenham, G.M. (2011) Iron Chelating Therapy for Transfusional Iron Overload. New England Journal of Medicine, 364, 146-156. https://doi.org/10.1056/NEJMct1004810

[8] Najafipour, F. (2008) Evaluation of Endocrine Disorders in Patients with Thalassemia Major. International Journal of Endocrinology and Metabolism, 2, 104-113.

[9] De Sanctis, V., Eleftheriou, A. and Malaventura, C. (2004) Thalassemia International Federation Study Group on Growth and Endocrine Complications in Thalassemia. Prevalence of Endocrine Complications and Short Stature in Patients with Thalassemia Major: Multicenter Study by the Thalassemia International Federation (TIF). Pediatric Endocrinology Reviews, 2, 249-255.

[10] Flynn, D.M., Hoffbrand, A.V. and Politis, D. (1982) Subcutaneous Desferrioxamine: The Effect of Three Years' Treatment on Liver, Iron, Serum Ferritin, and Comments on Echocardiography. Birth Defects Original Article Series, 18, 347-353.

[11] Borgna-Pignatti, C., Rugolotto, S., De Stefano, P., Zhao, H., Cappellini, M.D. and 
Del Vecchio, G.C. (2004) Survival and Complications in Patients with Thalassemia Major Treated with Transfusion and Deferoxamine. Hematologica, 89, 1187-1193.

[12] Ghosh, S., Bandyopadhyay, S.K., Bandyopadhyay, R., Roy, D., Maisnam, I. and Ghosh, M.K. (2008) A Study on Endocrine Dysfunction in Thalassemia. Journal of the Indian Medical Association, 106, 655-659.

[13] Mul, D., Fredriks, A.M., van Buuren, S., Oostdijk, W., Verloove-Vanhorick, S.P. and Wit, J.M. (2001) Pubertal Development in the Netherlands 1965-1997. Pediatric Research, 50, 479486.

[14] Forman, D.T. and Parker, S.L. (1980) The Measurement and Interpretation of Serum Ferritin. Annals of Clinical \& Laboratory Science, 10, 345-350.

[15] National Committee for Clinical Laboratory Standards (NCCLS) (1992) Evaluation of Precision Performance of Clinical Laboratory Devices. 2nd Edition, Tentative Guidelines, NCCLS Document, EP5-T2, Villanova, PA, NCCLS, March 1992.

[16] Clinical and Laboratory Standards Institute (2005) Interference Testing in Clinical Chemistry, Approved Guidelines. 2ond Edition, CLSI Document, EP7-A2, Wayne, PA, Clinical and Laboratory Standards Institute.

[17] National Committee for Clinical Laboratory Standards (NCCLS) (2004) Protocol for Determination of Limits of Detection and Limits of Quantification, Approved Guidelines. NCCLS, Document EP17A, Wayne, PA, NCCLS.

[18] Rose, G.T. (1985) Disorders of Ovary and Female Reproductive Tract. In: Wilson, J.D. and Foster, D.W., Eds., William Text Book of Endocrinology, Philadelphia, Saunders, 206-208.

[19] Cassinerio, E., Roghi, A., Orofino, N., Pedrotti, P., Zanaboni, L., Poggiali, E., Giuditta, M., Consonni, D. and Cappellini, M.D. (2015) A 5-Year Follow-Up in Deferasirox Treatment: Improvement of Cardiac and Hepatic Iron Overload and Amelioration in Cardiac Function in Thalassemia Major Patients. Annals of Hematology, 94, 939-945. https://doi.org/10.1007/s00277-014-2291-X

[20] Lu, M.Y., Peng, S.S., Chang, H.H., Yang, Y.L., Chen, C.A., Jou, S.T., Lin, D.T. and Lin, K.H. (2013) Cardiac Iron Measurement and Iron Chelation Therapy in Patients with Beta Thalassemia Major: Experience from Taiwan. Transfusion Medicine, 23, 100-107. https://doi.org/10.1111/tme.12014

[21] Vichinsky, E., Levine, L., Bhatia, S., Bojanowski, J., Coates, T. and Foote, D. (2012) Standards of Care Guidelines for Thalassemia. Children's Hospital and Research Center, Oakland.

[22] Ho, W.L., Chung, K.P., Yang, S.S., et al. (2013) A Pharmaco-Economic Evaluation of Deferasirox for Treating Patients with Iron Overload Caused by Transfusion-Dependent Thalassemia in Taiwan. Journal of the Formosan Medical Association, 112, 221-229.

[23] De Sanctis, V., Roos, M., Gasser, T., Fortini, M., Raiola, G. and Galati, M.C. Italian Working Group on Endocrine Complications in Non-Endocrine Diseases (2006) Impact of Long-Term Iron Chelation Therapy on Growth and Endocrine Functions in Thalassemia. Journal of Pediatric Endocrinology and Metabolism, 19, 471-480.

[24] Viprakasit, V., Ibrahim, H., Ha, S.Y., Ho, P.J., Li, C.K., Chan, L.L., Chiu, C.F., Sutcharitchan, P., Habr, D., Domokos, G., Roubert, B., Xue, H.L., Bowden, D.K. and Lin, K.H. (2011) Clinical Efficacy and Safety Evaluation of Tailoring Iron Chelation Practice in Thalassemia Patients from Asia-Pacific: A Sub Analysis of the EPIC Study of Deferasirox. International Journal of Hematology, 93, 319-328. https://doi.org/10.1007/s12185-011-0789-8

[25] Chang, H.-H., Lu, M.-Y., Peng, S.S.-F., Yang, Y.-L., Lin, D.-T., Jou, S.-T. and Lin, K.-H. (2015) The Long-Term Efficacy and Tolerability of Oral Deferasirox for Pa- 
tients with Transfusion-Dependent $\beta$-Thalassemia in Taiwan. Annals of Hematology, 94, 1945-1952. https://doi.org/10.1007/s00277-015-2476-y

[26] Iancu, T. (1990) Ultra Structural Pathology of Iron Overload with Special Reference to Endocrine Glands. In: Pintor, C., Corda, R. and De Sanctis, V., Eds., Workshop on Endocrine Problems in Thalassemia Venezia, San Marco Scientific Publications, 19-28.

[27] Aldouri, M.A., Wonke, B. and Hoffbrand, A.V. (1987) Iron State and Hepatic Disease in Patients with Thalassemia Major Treated with Long Term Subcutaneous Desferrioxamine. Journal of Clinical Pathology, 40, 353-359. https://doi.org/10.1136/jcp.40.11.1353

[28] Pemde, H.K., Chandra, J., Gupta, D., Singh, V., Sharma, R. and Dutta, A.K. (2011) Physical Growth in Children with Transfusion-Dependent Thalassemia. Pediatric Health, Medicine and Therapeutics, 2, 13-19.

Submit or recommend next manuscript to SCIRP and we will provide best service for you:

Accepting pre-submission inquiries through Email, Facebook, LinkedIn, Twitter, etc. A wide selection of journals (inclusive of 9 subjects, more than 200 journals)

Providing 24-hour high-quality service

User-friendly online submission system

Fair and swift peer-review system

Efficient typesetting and proofreading procedure

Display of the result of downloads and visits, as well as the number of cited articles Maximum dissemination of your research work

Submit your manuscript at: http://papersubmission.scirp.org/

Or contact ojbd@scirp.org 